\title{
Coupling of Currencies: An INR and USD Perspective
}

Mayuree Barik ${ }^{*}$ and Aparna Rao ${ }^{\dagger}$

\begin{abstract}
This paper aims to explore the relationship between the Indian Rupees (INR) and USDollars (USD). It further tries to identify whether the volatility of exchange rates is affected by various events. Bivariate causality tests have been run on the exchange rates of INR and USD which have revealed a coupled relationship between them. Further, it was found that the magnitude of the impact on the volatility of exchange rates varies according to the nature of the event.
\end{abstract}

Keywords: Bivariate Granger Causality, Bretton Woods System, Currency Coupling, Currency Volatility, Demonetisation, Exchange Rates

\section{Introduction}

Trade and commerce date back as far as 9000 BC. Hunters and gatherers began settling down near river banks to grow crops and rear cattle. This change gave rise to the system of barter trade, where a man could swap something of value to procure something else of worth. Precious metals, shells, livestock, grains and so on were the "currency" he could use to trade. This was the earliest form of currency known to mankind. Over the centuries, trade, commerce, and currency have evolved at an astounding rate. Today, currency not only means paper currency but also E-Wallets and Bitcoins. Globalisation has erased the virtual borders between countries and has opened up economies. As different countries

\footnotetext{
*Western Michigan University, USA; mayuree.barik@wmich.edu † Virginia Commonwealth University, Virginia; raghavendrara@vcu.edu
} 
have their own currency, the concept of foreign exchange has come up. Products and services are traded between countries all around the globe and one can pay using his country's currency and be paid in foreign currency. Foreign currency is bought and sold, earned by trading in international stock markets and so on. It remains to be seen how currency further evolves in the future. Currency is an indispensable part of our daily lives.

It is well known that currencies have different values when measured in terms of other currencies, for example, $\$ 1=$ Rs. 70. What one dollar buys you in the USA may buy you a little more in India. But the questions to be asked are, 'Is there more to this relationship?' and 'Is there more of a correlation between currencies than this?'.

Like shares, currencies can be highly correlated in nature. As in, the movement of one country's currency may have a minor or major impact on the movement of another country's currency. Commodities and currencies can also be correlated in nature. Correlation between currencies can be measured and said to be positive, negative or zero. When two currencies are positively correlated (correlation of +1 ), they tend to move together in the same direction but when they are negatively correlated (correlation of -1), they move in opposite directions of each other; but, zero correlation means that their movement is independent of each other.

Examples given for these are, EUR/USD \& USD/GBP for positively correlated currencies and EUR/USD \& USD/CHF for negatively correlated currencies. That is, when the EUR/USD increases (trade), the USD/GBP increases as well but the same impacts USD/CHF badly and it decreases (OCTAFX, n.d.).

The Rupee has depreciated steadily against the US Dollar. Misra \& Gupta (2017) have stated that the Rupee began depreciating against the Dollar since the year 1993. In their paper, they have tried to analyse the relationship between the Rupee and the Dollar using various statistical tools.

Now that it has been established that currency rates do impact each other and are impacted by each other, the next question to be asked is "Are exchange rates affected by major events of financial nature 
or otherwise? And to what extent?". Share markets are known to react greatly to events in the country for example, elections in a country are known to impact financial markets majorly. But does the same hold good in case of exchange rates?

In this paper, two economies-India and the United States have been considered and the recent developments in each country have been examined to find out how these changes affect the exchange rate of their respective countries. The dependency between Indian Rupees and the United States Dollar has also been explored in this paper.

Thus, the objectives of the research are as follows

1. To find the extent of dependency between the US dollars (USD) and Indian Rupees (INR)

2. To identify whether the volatility of the exchange rates of the currencies: Indian Rupees (INR) and US Dollars (USD) are impacted by various events

\section{Literature Review}

The year 1972 was an eventful year for economists and the field of economics in general with various noteworthy events including the rapid price increase mainly in European countries, the survival of the Smithsonian Agreement, an increasing focus on controlling inflation, Italy moving towards a two-tier exchange system at the beginning of the year 1973 to name a few. Many economists have tried investigating the relationship of two currencies with each other and with various other variables such as stock prices and inflation rates.

In 1972, Heckerman (1972) tried to find out if the Present Discounted Value (PDV) affects the foreign income earned by firms in any way. Therefore, PDV has been used as a major determinant to measure the economic fluctuations in terms of any variation in foreign operations. One of the highlights of this paper is finding whether the fluctuations in the exchange rate have a greater impact on the manufacturing process of an American firm that produces to meet the demands of a foreign market than firms located elsewhere in the world with their facilities located in other countries. 
The year 1975 saw the publication of a paper based on a twocountry model by Shapiro (1975).

The 1980s were a period of extensive research and a multitude of papers on the subject matter were published by highly commended economists such as Dornbusch and Fischer (2018) who modelled various theories linking exchange rates and inflation rates.

The 1990s started off with Jorion (1990) publishing his paper on the investigation of the effect of exchange rates on the stock returns of US Multinationals. In his second paper titled "Price of Exchange rate risk in the stock market", Jorion (1991) stated that since stock prices vary across different industries, it can be considered as a determinant for fluctuating exchange rates.

Fama (1990) focussed on the relationship between exchange rates and stock prices where the subject was negative relations between stock relations and inflations due to a negative relation between inflation and real activity. Mark (1995) tested whether the exchange rate can prevail for long time periods or shorter time periods. Dornbuschin (1976) tried to develop a theory of exchange rate movements where the capital structure was consistent. Similarly, a paper by Frankel (1979) further explored the relationship between exchange rate and inflation rate by deriving an equation taking into consideration the money supply, relative income level, the nominal interest differential and the expected long-run inflation differential.

Ghosh, Gulde, Ostry \& Wolfin (1996) published a paper that dealt with how exchange rates lead to less variability in the inflation rate, leading to better performance of the economy. Cushman (1983) studied the effect of exchange rate on multinational corporations by taking 14 bilateral countries and then studying the effect of exchange rates on these countries. The conclusion was that the exchange rate directly affects the performance of multinational corporations trading in bilateral countries.

The main objective of the paper published by French, Ruback, and Schwert (1983) was to understand whether the income generated due to unexpected inflation was the cause of stock returns, where the outcome was that the wealth generated due to unexpected inflation is indirectly proportional to stock returns. 
Flannery and James (1984) worked on Common stock returns of Financial Institutions where it was found that the returns from these financial institutions are directly proportional to interest rates. Ball (1999) tested the Swenson Ball model in open economies in his paper "Policy Rules for Open Economies". Further, Dornbusch and Fischer (1980) stated the fact that the sensitivity of long-term investments depends on expectation on inflation and consumption in future whereas the paper published in 1984 states how hedging can be used to control exchange rates. Another such paper was published by Frankel (1999) where he came to the conclusion that there is no single currency that is right for all countries all the time. However, it depends on the circumstances of a particular country.

Taylor (2001) emphasised on the concept of the exchange rate and inflation by focussing on the issue of the reaction of the interest rate on the exchange rate of the country. Levy-Yeyati \& Sturzenegger (2001) concluded that there is a negative relationship between exchange rate and inflation. Levy-Yeyati and Sturzenegger (2003) also concluded that exchange rates matter for the economic performance of non-industrial countries.

Gal and Monacelli, (2005) speaking on the subject "Monetary Policy and Exchange Rate Volatility in a small open economy", arrived at the conclusion that the effects of the pegged exchange rate are similar to both open and closed economy since equilibrium conditions are both similar for both. Choudhri and Hakura (2003) also explored a similar field and found that the exchange rate is directly influenced by inflation. Hereon, this relationship should be taken into account while framing monetary policies.

Hassanain (2005) tried to find out the relation between real exchange rate and the black-market exchange rate in developing countries. The results suggested that the exchange rate is affected by the black-market exchange rate. However, it depends on the purchasing power parity of a person (PPP).

A similar study by Ajevskis and Vitola (2011) was carried out to find the effect of inflation on a fixed exchange rate. For this study, some Baltic states were taken and after conducting the study, the conclusion was that due to the fixed exchange rate policy, the effect 
of inflation is negligible. The Effect of Balance of Payments (BOP) was studied in the paper "Exchange Rates, Growth \& Inflation" by Barbosa-Filho (2006) where they stated that BOP is a potential instrument in determining the exchange rate and fostering the exchange rate and growth development of an economy.

Naghdi and Kaghazian (2015) tried to understand the effect of the Exchange rate on inflation rate in Iran,where the conclusion was that Iran's foreign exchange heavily depended upon oil price changes. Ghosh (2015) used the Granger Causality test to understand the NIFTY and SENSEX market and the dynamics of their relationship. Economists Aleemi, Tariq, and Ahmed (2016) commented on the role of gold prices and exchange rates on the continuous inflation in Pakistan. In their paper, they have agreed upon the fact that the price of gold, exchange rate and inflation are directly proportional to the inflation in the long run. El Achnab (2016) talks about how the targeting of inflation and fixed rates increase economic performance. Another study conducted by Ghosh (2016) compared the Hang Seng and Shanghai stock exchange. It was discovered that the Hang Seng stock market was driven by Shanghai.

The most recent research on the topic is titled "Exchange Rates and Monetary Spillovers" by Plantin and Shin (2018). The method used was a flexible exchange rate version of the Mundell-Fleming Model. They arrived at the conclusion that floating exchange rates guarantee more monetary autonomy as capital flows more smoothly into a small open economy.

In the case of INR and the US, there have been speculations about the correlation between the two currencies. The INR has in recent times depreciated against the USD. This adversely impacted the Indian economy due to the amount of fiscal and current account deficit as stated by Singh, Mishra, and Singh (2016).

The current year has been rather tumultuous for the Indian economy in general with the Rupee hitting an all-time low, standing at 73.77 against $\$ 1$ in October. Two months later, the situation, though slightly better, is not very optimistic. 


\section{Research Methodology}

For the purpose of this study, the data consisting of exchange rates, both for the Indian Rupee and the US Dollar were considered. The data considered was secondary, time series data and showed day to day variations in the exchange rates of the two currencies respectively. The data considered spanned across the years 1997 2018 . Hence, the analysis done in this paper is retrospective and not predictive. The tool used to analyse the data was the Bivariate Granger Causality Test. The objective of this test was to examine the level of dependency of the two currencies on each other if at all such a relationship exists. The data set consisted of 10,522 data points.

The hypotheses used to conduct the Bivariate Granger Causality Test for the time series data $X(t)$ and $Y(t)$ were as follows:

H0: There is a relationship and a certain degree of dependency between the Indian Rupee (INR) and the USD

Ha: There is no relationship or a certain degree of dependency between the Indian Rupee (INR) and the USD

The hypotheses can be further written as follows:

$\mathrm{Y}=\mathrm{f}(\mathrm{X})$

$\mathrm{HO}:{ }^{\prime} \mathrm{X}^{\prime}$ is not Granger causing ' $\mathrm{Y}$ '

$\mathrm{H} 1$ ' $^{\prime}$ ' is Granger causing ' $Y$ '

$\mathrm{X}=\mathrm{f}(\mathrm{Y})$

$\mathrm{H0:}$ ' $\mathrm{Y}$ ' is not Granger causing ' $\mathrm{X}$ '

$\mathrm{H} 1$ ' $^{\prime}$ ' is Granger causing ' $\mathrm{X}$ '

Hence, the equations have been arrived at with reference to the work by Joseph (2018) in the paper "Driver - Driven relationship between the Tokyo Stock Exchange Indices - TOPIX and NIKKEI" and "Testing for Granger Causality between stock prices and economic growth" by Foresti (2007):

$$
\begin{aligned}
& Y(t)=\alpha+\sum_{i=1}^{p} a Y_{t-i}+\sum_{j=1}^{q} b_{j} X_{t-j}+\varepsilon_{i}(1) \\
& X(t)=\beta+\sum_{i=1}^{r} c_{i} X_{t-i}+\sum_{j=1}^{s} d_{j} Y_{t-j}+n_{i}(2)
\end{aligned}
$$


Which can be further modified to :

$$
\begin{aligned}
& (U S D)_{t}=\alpha+\sum_{i=1}^{p} a(\text { USD })_{t-i}+\sum_{j=1}^{q} b_{j}(I N R)_{t-j}+\varepsilon_{i}(1) \\
& (I N R)_{t}=\beta+\sum_{i=1}^{r} c_{i}(I N R)_{t-i}+\sum_{j=1}^{s} d_{j}(U S D)_{t-j}+n_{i}(2)
\end{aligned}
$$

An online statistic and forecasting software, Wessa (2016) was used to conduct the Bivariate Granger Causality Test.

\section{Results}

\section{X: Indian Rupee \\ Y: US Dollar}

Table 1.0: Granger Causality Test $Y=f(X)$

\begin{tabular}{llllll}
\hline \multicolumn{3}{l}{ Granger Causality Test: $\mathrm{Y}=\mathrm{f}(\mathrm{X})$} & & & \\
Model & Res.DF & Diff. DF & $\mathrm{F}$ & $\mathrm{p}$-value & Occurrence \\
\hline Complete model & 5257 & & & & \\
Reduced model & 5258 & -1 & 1.12167 & 0.289608 & $71 \%$ \\
\hline
\end{tabular}

The p-value $(0.289608)$ is greater than alpha (0.050). Therefore, it fails to reject null hypothesis (Refer to Table 1.0)

Table 1.1: Granger Causality Test $\mathrm{X}=\mathrm{f}(\mathrm{Y})$

\begin{tabular}{llllll}
\hline Granger Causality Test: $\mathrm{X}=\mathrm{f}(\mathrm{Y})$ & & & \\
Model & Res.DF & Diff. DF & $\mathrm{F}$ & p-value & Occurrence \\
\hline Complete model & 5257 & & & & \\
Reduced model & 5258 & -1 & 0.832045 & 0.361724 & $64 \%$ \\
\hline
\end{tabular}

The p-value (0.361724) is greater than alpha (0.050). Therefore, it fails to reject the null hypothesis (Refer to Table 1.1) 
Barik and Rao Coupling of Currencies: An INR and USD Perspective
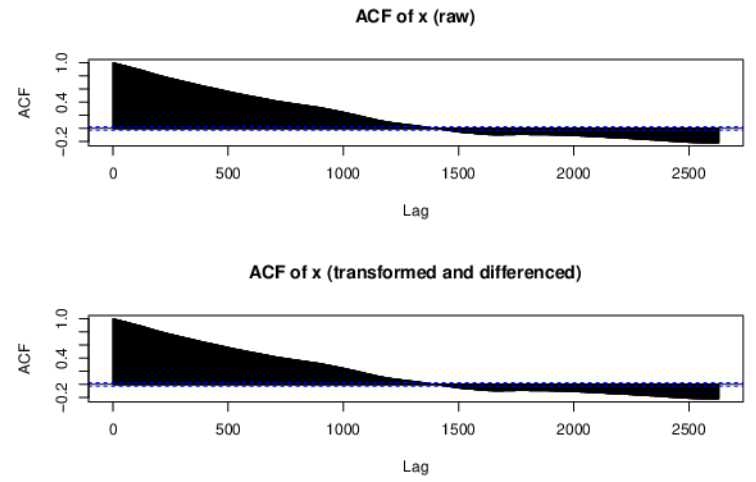

Fig1.0: ACF Chart of $X$
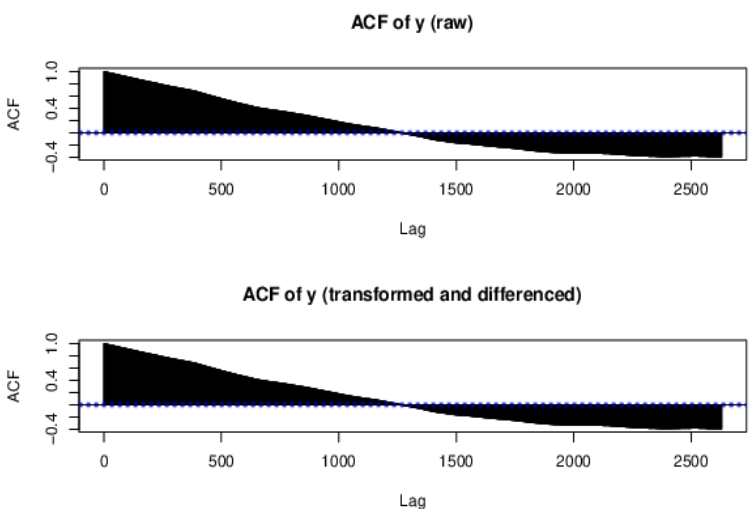

Fig 1.1 ACF Chart of $Y$

\section{Interpretation}

Using the Bivariate Granger Causality, we can observe that the Exchange Rate of the USD and the Indian Rupee are correlated and dependant on each other. From the above result, we can say that the USD shows a higher degree of dependency on the Indian Rupee (71\%) than the Rupee on the USD (64\%). Hence the relations are coupled. Currencies are often found to be coupled when trade relations are robust and long-lasting. 
In the above case (Fig no $1.0 \& 1.1$ ), the correlogram is a flat chart. Thus, the series exhibits the property of moving averages. The Moving Average Series has been found to be driven by momentum i.e. the future values are driven by past values.

In the first case (Table No 1.0), $Y=f(X)$, the p-value $(0.289608)$ is more than alpha (0.050). Therefore, since $p>a$, we fail to reject the null hypothesis, ' $\mathrm{X}$ ' is Granger causing ' $\mathrm{Y}$ '.

Therefore, it can be concluded that the INR is Granger causing the USD.

In the second case (Table No 1.1), $\mathrm{X}=\mathrm{f}(\mathrm{Y})$, the $\mathrm{p}$-value $(0.361724)$ is more than alpha (0.050). Therefore, since $p>a$, we fail to reject the null hypothesis, ' $Y$ ' is Granger causing ' $X$ '.

Therefore, it can be concluded that the USD is Granger causing the INR.

Table 1.3 Comparision of the Currency Volatility of INR and USD after various events.

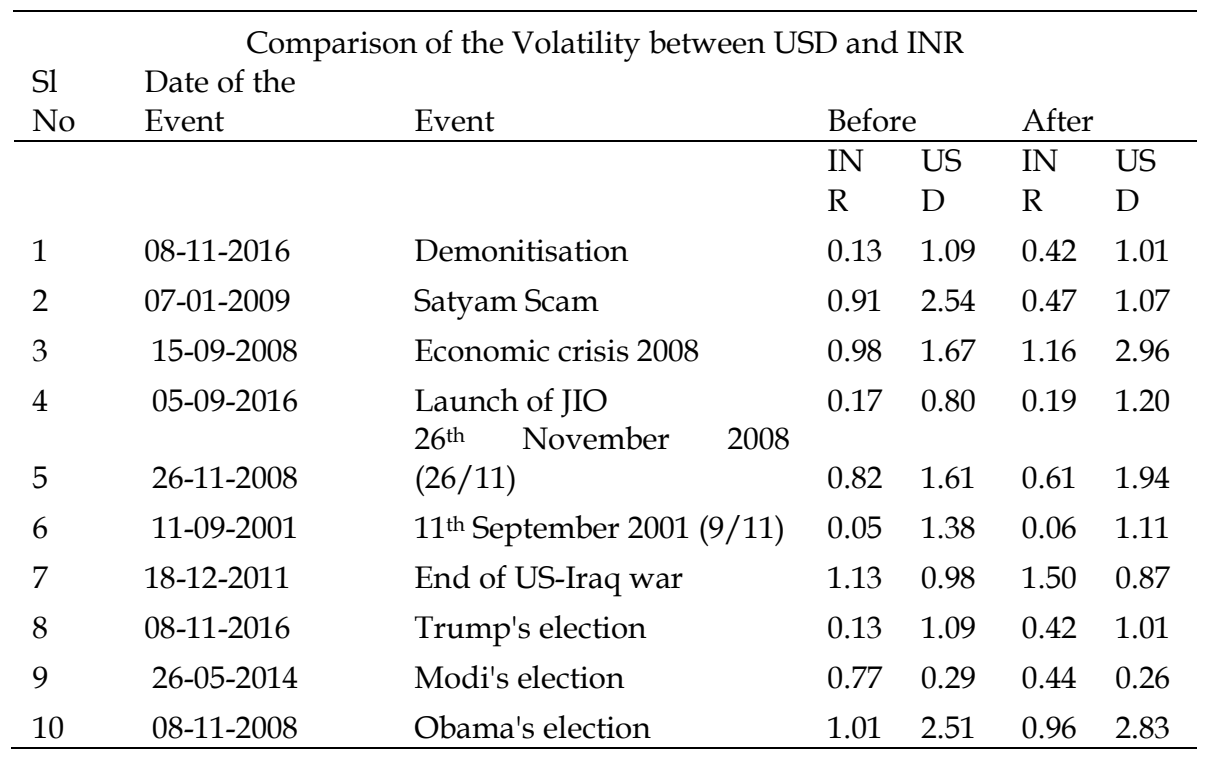

Comparison of the volatility of the exchange rates of currencies INR and USD after the occurrence of various events (Refer to Table 1.3) 


\section{Observations}

1. There is no significant change in the standard deviations (volatility) of the INR and USD after war or terrorism as seen in the cases of 9/11, 26/11 and the US-Iraq war. Hence, it can be said that exchange rates tend to remain unaffected by war and terrorism.

2. The Satyam scam is a noted event in Indian financial history when the company's director through a letter to the shareholders exposed the scam in the company due to the inflation in the value of debtors and the window dressing of the balance sheet. This brought about a significant change in the volatility of both the INR and USD. This could be due to the fact that most of Satyam's clients were based out of the USA. Thus, the value of the USD came down.

3. The volatility of the USD during the Economic Crisis of 2008 surged from 1.67 to 2.96 mainly due to the concentration of the crisis in the United States of America.

4. Since President Donald Trump has had mixed reactions to being elected as a presidential candidate, the effect on the USD was seen immediately after him being elected as the President. The USD has fallen down to 1.01 from the previous 1.09

5. On $8^{\text {th }}$ November 2016 IST 8 pm when Prime Minister Narendra Modi announced Demonetisation, it had a huge impact on the Indian Economy. As the supply of Indian Currency of higher denominations was pulled out of circulation, people were forced to switch to cashless transactions. The circulation of money in the economy was tightened. Hence, there was a sharp rise in the volatility of the INR (0.42 from 0.13$)$.

\section{Conclusion}

An analysis of the standard deviations of both the INR and USD before and after major events certainly brings some interesting observations to light. While stock markets tend to react negatively or positively to major events in the country, exchange rates seem to fluctuate in case the event is of a particular nature only. This can be 
proven by closely observing Table 1.3 which depicts the currency volatility after the occurrence of some major events. Upon observing closely, it can be seen that unforeseen events like demonetisation and Satyam events affect the volatility of exchange rates to a large extent. On the other hand, it can also be concluded that events like wars or terrorism have a less or negligible impact on the volatility of the exchange rate of a country. But, one of the most interesting observation was that in order to maintain the volatility of the exchange rate in a country, opinion and attitude of its masses towards its leader is important. This can be observed from Table 1.3 when the value of USD dropped to 1.01 from 1.09, which can be attributed to the fact that the public had mixed reactions upon him being elected as the president of the United States. Also, through the research conducted, it has been found that strong trade relations exist between the USA and India. Martin and Kronstadt (2007) have stated that one reason for strong trade relations between the US and India is that the US Government considers India a lucrative market and attractive to foreign investors. There also exists a strategic alliance between India and the USA. It has been stated in a report by the Council on Foreign Relations by Blackwill, Chandra, and Clary (2011) that it is in the USA's interest that India be more powerful in the international arena.

The results show success in identifying certain interesting factors that affect the volatility of Indian and USD volatility exchange rate. Further, these factors have not been discussed before in any research paper. Therefore, through this research, we have obtained some interesting outcomes, which have scope for further study.

\section{References}

Arora, A., Rathore, H., Agrawal, R. R., Chavan, S., \& Nayak, S. (n.d.). What determines US Dollar - Indian Rupee exchange rate movements - An empirical analysis of the falling Rupee. Indian Institute of Technology, 1-20.

Ajevskis, V., \& Vitola, K. (2011). Fixed Exchange rate versus inflation targeting: evidence from DSGE modelling. Working Papers 2011/02, Latvijas Banka, (January 2011).

Aleemi, A. R., Tariq, M., \& Ahmed, S. (2016). The role of Gold Prices, exchange rate and interest rate on the continuity of inflation in 
Pakistan. Pakistan Business Review, (March), 37-54.

Ball, L. (1999). Policy Rules for Open Economies (Vol. I).

Barbosa-Filho, N. (2006). Exchange rates, growth and inflation. Annual Conference on Development and Change, (September), 17-20. Retrieved from http://www.policyinnovations.org/ ideas/ policy_library/ data/01383/_res/id=sa_File1/Barbosa_paper_v1.pdf

Blackwell, R. D., Chandra, N., \& Clary, C. (2011). The United States and India: A Shared strategic future. Aspen Institute India, 1-67.

Choudhri, E. U., \& Hakura, D. S. (2003). Exchange rate pass-through to domestic prices: does the inflationary environment matter?, (December 2001, Revised 2003).

Cushman, D. O. (1983). The effects of real exchange rate risk on international trade. Journal of International Economics, 45-63.

Dornbusch, R. \& Fischer, S. (1980). Exchange rates and the current account. The American Economic Review, 960-971.

Dornbusch, R. (1976). Expectations and exchange rate dynamics. Journal of Political Economy, 84(6), 1161-1176.

El Achnab, H. J. (2016). Exchange rate regime, inflation targeting and macroeconomic performance. International Journal of Economics and Finance, 8(8), 143. https:/ / doi.org/10.5539/ijef.v8n8p143

Fama, E. F. (1990). Stock returns, expected returns and real activity. The Journal of Finance, 1089 - 1108.

Flannery, M. J., \& James, C. M. (1984). The effect of interest rate changes on the common stock returns of financial institutions. The Journal of Finance, 39(4), 1141-1153.

Frankel, J. A. (1979). A theory of floating exchange rates based on real interest differentials. The American Economic Review, 69(4), 610-622. Retrieved from http://www.jstor.org/stable/1808707\%0Ahttp://about.jstor.org/ter $\mathrm{ms}$

French, K. R., Ruback, R. S., \& Schwert, G. W. (1983). Effects of nominal contracting on stock returns. The Journal of Political Economy, 91(1), 7096. Retrieved from https://www.jstor.org/stable/1840431 Effects of Nominal Contracting o,

Gal, J., \& Monacelli, T. (2005). Monetary policy and exchange rate volatility in a small open economy, 707-734.

Ghosh, A. R., Gulde, A.-M., Ostry, J. D., \& Wolf, H. (1996). Does the exchange rate regime matter for international trade? IMF Economic Issues, 2, 19. https:// doi.org/10.3386/w5874

Ghosh, B. (2015). A statistical analysis of the stochastic drift between Sensex \& Nifty- An in-depth study. International Journal of Innovative Research \& Development, 4(5), 12-16. https:// doi.org/ 10.2307/ 1905515.E.L. 
Ghosh, B. (2016). Do the dragons move together; co-integrated and causality study among chinese bourses-A curious case of Hang Seng and Shanghai Stock Exchange. Al-Barkaat Journal of Finance $\mathcal{E}$ Management, 8(2), 1. https://doi.org/10.5958/2229-4503.2016.00010.2

Hassanain, K. (2005). The real exchange rate and the black market exchange rate in developing countries. Empirical Economics, 30(2), 483492. https://doi.org/10.1007/s00181-005-0246-8

Heckerman, D. (1972). The exchange risks of foreign operations. The Journal of Business, 45(1), 42-48.

Jorion, P. (1991). The pricing of exchange rate risk in the stock market. The Journal of Financial and QuantitativeAnalysis, 26(3), 363-376.

Jorion, P., \& Multinationals, U. S. (2018). The exchange-rate exposure of U. S. multinationals. The Journal of Business, 63(3), 331-345.

Levy-yeyati, B. E., \& Sturzenegger, F. (2003). American Economic association to float or to fix : evidence on the impact of exchange rate regimes on growth. The American Economic Review, 93(4), 1173-1193.

Levy-Yeyati, E., \& Sturzenegger, F. (2001). Exchange Rate regimes and economic performance, 47, 62-98.

Mark, N. C. (1995). American Economic Association Exchange rates and fundamentals : evidence on long-horizon predictability. The American Economic Review, 85(1), 201-218. Published by American Economic, 85(1), 201-218.

Martin, M. F., \& Kronstadt, K. (2007). India - U.S. Economic and Trade Relations. CRS Report for Congress, 1-66.

Misra, P., \& Gupta, J. (2017). US-INR Exchange Rate Movements: An Empirical Analysis of Macroeconomic Determinants. Amity Journal of Economics, 23-34.

Naghdi, Y., \& Kaghazian, S. (2015). The Effects of asymmetric transmission of exchange rate on inflation in Iran: Application Of threshold models. Studies in Business and Economics, 10(2), 99-114. https:/ / doi.org/10.1515/sbe-2015-0023

Plantin, G., \& Shin, H. S. (2018). Exchange rates and monetary spillovers, 13, 637-666.

Shapiro, A. C. (1975). American Finance Association Exchange Rate changes, inflation, and the value of the multinational corporation. The Journal of Finance, 30(2), Papers and Proceedings of the Thirty-Third Annual Meeting, 30(2).

Singh, A., Mishra, V., \& Singh, A. B. (2016). Impact of Rupee-Dollar Fluctuations on Indian Economy. Retrieved April, 18, 2018.

Taylor, J. B. (2001). The role of the exchange rate in monetary-policy rules. American Economic Review, 91(2), 263-267.

Wessa. (2016). Retrieved from http:// www.wessa.net/ rwasp_ grangercausality.wasp/ 